Int. J. Dev. Biol. 52: 333-344 (2008)

doi: $10.1387 / \mathrm{ijdb} .072486 \mathrm{cr}$

\title{
The distribution and behavior of extragonadal primordial germ cells in Bax mutant mice suggest a novel origin for sacrococcygeal germ cell tumors
}

\author{
CHRISTOPHER RUNYAN ${ }^{1}$, YING GU ${ }^{1}$, AMANDA SHOEMAKER ${ }^{1}$, LEENDERT LOOIJENGA ${ }^{2}$ \\ and CHRISTOPHER WYLIE ${ }^{1, *}$ \\ ${ }^{1}$ Division of Developmental Biology, Cincinnati Children's Hospital Research Foundation, Cincinnati, OH, USA and \\ ${ }^{2}$ Department of Pathology, Erasmus University Medial Center, Josephine Nefkens Institute, Rotterdam, The Netherlands
}

\begin{abstract}
In the mouse, germ cells that do not reach the genital ridges rapidly die by a wave of apoptosis that requires the pro-apoptotic protein Bax. In Bax-null embryos, large numbers of ectopic (extragonadal) germ cells fail to die. We have studied the fates of these, in an effort to understand the etiology of human extragonadal germ cell tumors, which are thought to arise from ectopic germ cells. We find that ectopic germ cells in which apoptosis is blocked form a heterogeneous population, which partially differentiates along the gonocyte pathway to different extents in different regions of the embryo, and in the two genders. In particular, a previously undescribed population of ectopic germ cells was identified in the tail. These germ cells retained primitive markers for longer than ectopic germ cells in other regions, and represent a possible origin for sacrococcygeal type l extragonadal germ cell tumors found in neonates and infants. This hypothesis is supported, but not proved, by the finding of cells expressing the germ cell marker Oct4 associated with a coccygeal germ cell tumor in a human infant.
\end{abstract}

KEY WORDS: germ cell, tumor, extragonadal teratoma

\section{Introduction}

The goal of this work was to understand the behavior of primordial germ cells (PGCs) that may underlie the formation of extragonadal germ cell tumors (EGCTs). In the normal embryo, primordial germ cells form during gastrulation, and migrate through the posterior primitive streak into the forming hindgut. At midgestation they leave the hindgut into the midline dorsal body wall, and migrate laterally into the developing genital ridges. This process occurs in the mouse from E7.5 to 11.5, and in the human from 4 to 5 weeks of development. Time-lapse movies, using a mouse line expressing eGFP in the migrating germ cells, have shown that at E10.5, the PGCs form two populations; those nearest to the genital ridges continue to migrate and colonize the genital ridges, whereas those still in the midline dorsal body wall rapidly die by apoptosis (Molyneaux et al., 2001). Later studies showed that midline germ cell death is caused by down-regulation of the expression of Steel factor, an essential survival factor for germ cells, in the midline (Runyan et al., 2006). Furthermore, the pro-apoptotic Bcl2 family member Bax was found to be an essential downstream effector of the loss of Steel factor, and its absence rescues germ cell death in the absence of Steel factor. In the absence of Bax in wild type embryos, midline germ cell death is abrogated, resulting in large numbers of extragonadal germ cells (Runyan et al., 2006, Stallock et al., 2003).

The availability of embryos in which ectopic germ cell death is inhibited, and which carry a fluorescent marker allows the study of the behavior and fate of midline germ cells that would normally die by apoptosis. In this work, we have used these embryos to try to understand some aspects of the origins of EGCTs, which arise almost exclusively in midline structures, and are widely thought to arise from PGCs that fail to die in the midline by apoptosis (Beard, 1904, Schneider et al., 2001). In the USA, germ cell tumors (GCTs) constitute $7 \%$ of tumors in children under 20 years of age (Bernstein L, 1999), and are one of the most common neoplasms of infancy. One major unexplained aspect of GCTs is the consis-

Abbreviations used in this paper: EG, embryonic germ (colony); EGCT, extragonadal germ cell tumor; eGFP, enhanced green fluorescent protein; MVH, mouse vasa homolog; PGC, primordial germ cell.

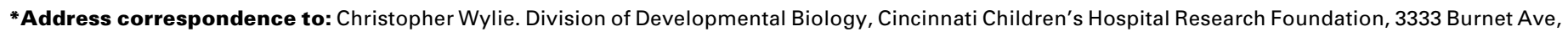
Cincinnati, OH 45229, USA. e-mail: Christopher.Wylie@cchmc.org
} 
tent variation in gender prevalence, location, and tumor type, seen in tumors that arise at different times of life (Table 1) (Oosterhuis and Looijenga, 2005, Oosterhuis et al., 2007). From both a clinical and a pathobiological point of view it is informative to separate GCTs into different groups. Type I GCTs occur in neonates and infants, are predominately benign teratomas or malignant yolk sac tumors, are more common in females (7:3 female:male ratio), and usually occur extragonadally (66\%). Type II GCTs are always malignant, occur in adolescence and young adulthood, most commonly in males (77\%), and are usually found within the gonads (80\%) (Bernstein L, 1999, Schmoll, 2002). Type II GCTs are usually seminomas that may or may not differentiate into non-seminomatous tumor types including embryonal carcinomas and choriocarcinomas, as well as yolk sac tumors and teratomas. Unlike most type I GCTs, type II GCTs have specific chromosomal anomalies, including gain of the short arm of chromosome 12. The most common location of neonatal and infantile GCTs is the sacrococcygeal region (Gobel et al., 2000), whereas in adolescents EGCTs form predominantly in the anterior mediastinum, CNS and retroperitoneum (Dehner, 1990, Gatcombe et al., 2004). Cytogenetic and epigenetic differences between the type I EGCTs (i.e. infantile sacrococcygeal teratomas), and type II adolescent mediastinal EGCTs suggest that the former arise from pre-meiotic, early migratory germ cells, whereas the latter arise from late- or post-migratory germ cells that may be arrested in the first meiotic prophase (Chaganti et al., 1994, Schneider et al., 2001, Wagner et al., 1997). Previous studies identified extragonadal germ cells that had entered meiosis within the adrenal glands (Upadhyay and Zamboni, 1982, Zamboni and Upadhyay, 1983), supporting the notion that EGCTs could arise from meiotic germ cells.

To gain an understanding of how these differences might arise, it is important to see whether extragonadal germ cells in the embryo behave differently in different regions of the embryo, and in the two genders. We show here, using $\mathrm{Bax}^{-/}$embryos in which the migratory germ cells are labeled with eGFP, that extragonadal germ cells do, in fact, behave differently, both in different locations and between the two genders. These studies also identify a previously unidentified population of extragonadal germ cells in the tail of the embryo, and suggest a possible origin for sacrococcygeal type I EGCTs.

\section{Results}

In a previous publication, we reported that extragonadal germ cells in $\mathrm{Bax}^{-/}$embryos disappear during late gestation (Stallock et al., 2003). There are three possible reasons for this: first, a Baxindependent mechanism of germ cell death; second, loss of the Oct4 $\triangle P E-E G F P$ transgene due to conversion of the germ cells into other tissues; or third, loss of transgene expression due to continued differentiation of the PGCs along the germ cell lineage. In the female, germ cells enter meiosis after they reach the genital ridges, and down-regulate Oct4. Male germ cells also downregulate Oct4 late in gestation. The only previous reports of extragonadal germ cells describe them in the adrenal glands, and perigonadal tissues, where they were found to enter meiosis (Francavilla and Zamboni, 1985, Upadhyay and Zamboni, 1982, Zamboni and Upadhyay, 1983). This would be expected to involve the loss of Oct4 expression.
We therefore stained sections and whole mounts of $\mathrm{Bax}^{-/-}$, Oct4 $\triangle \mathrm{PE}-\mathrm{EGFP}^{+}$transgenic embryos with markers of germ cell differentiation, to test the hypothesis that some differentiation normally found in gonocytes also occurs in extragonadal germ cells that have not reached the gonads.

\section{Extragonadal germ cells turn on Mouse Vasa Homolog (MVH), and lose Oct4DPE-EGFP expression}

Figures $1 A$ and $B$ show whole mounts of dorsal body walls from $\mathrm{Bax}^{-/-}$, Oct4 $\mathrm{PE}-\mathrm{EGFP}^{+}$male and female embryos. GFP ${ }^{+}$ extragonadal germ cells survived within the midlines of $\mathrm{Bax}^{-/}$ embryos, increasing in number until E14.5, then decreasing slowly, until none could be found after the first postnatal week. Heterozygous Bax littermates had fewer midline germ cells at $\mathrm{E} 12.5$, and none remained at E17.5. Whole mounts were also stained with an antibody specific for the MVH protein, which is normally up-regulated in germ cells when they reach the genital ridges, and remains on throughout embryogenesis and in spermatocytes postnatally (Tanaka etal., 2000). Figure $1 \mathrm{C}$ shows that extragonadal germ cells express MVH protein at E17.5, even though they have not entered the genital ridges. At postnatal day 2 , clusters of MVH-positive cells could be seen in the midline, some of which are strongly positive for GFP, some weakly positive, and some expressing only MVH (Fig. 1 C,D). These data suggest that the disappearance of the GFP marker reported previously in extragonadal germ cells (Stallock et al., 2003) is partially due to the loss of the marker transgene. Although MVHexpression is thought to be restricted to germ cells (Toyooka etal., 2000), these data do not formally exclude the possibility that in Bax-null embryos, a population of MVH-positive cells arise independently of the Oct4+ $4^{+}$germ cells.

No MVH-positive cells were found in sections through midline abdominal structures from 6 month-old $\mathrm{Bax}^{-/-}$mice, suggesting that there is either further loss of germ cell identity in the extragonadal cells, or a later, Bax-independent germ cell death. Germ cell-specific lineage analysis will be required to distinguish between these possibilities.

To find where extragonadal germ cells are located in $\mathrm{Bax}^{-/}$ embryos, we carefully examined serial sections for cells expressing Oct4 (and therefore GFP) and/or MVH. The greatest number of extragonadal PGCs was invariably found within the abdominal midline dorsal body wall, usually associated closely with large vessels such as the aorta and renal arteries, particularly at branch points (Figs. 1E,F). From E14.5 onwards, they were also found along the major intestinal vasculature (eg. celiac artery and

\section{TABLE 1}

\section{CHARACTERISTICS OF TYPE I AND II GERM CELL TUMORS}

\begin{tabular}{lcc} 
& Type I & Type II \\
\hline Age group & Neonates and infants & Adolescents and young adults \\
Predominant location & Sacrococcygeum & Testes \\
Gender prevalence & Female & Male \\
Histology & Teratoma & Seminoma \\
Cytogenetic anomalies & Yolk Sac Tumor & Nonseminoma \\
& None (teratoma) & Aneuploidy \\
Precursor cell & Gain 1p,4q,6q & Loss 1p,11,13,18, \\
& Unidentified & Gain $7,8,12 \mathrm{p}, 21, \mathrm{X}$ \\
& & Carcinoma in situ
\end{tabular}


inferior mesenteric vein), in and around the adrenal glands (Fig. $1 \mathrm{G})$, in the mesenteries of the intestines, the umbilicus, and immediately outside the gonads, consistent with earlier reports (Francavilla and Zamboni, 1985). GFP-positive cells were also observed within the thymus (Fig. $1 \mathrm{H}$ ) and retina (not shown), but in these locations their morphology was not germ cell-like, and they were also present in $\mathrm{E} 17.5 \mathrm{Bax}^{+/-}$embryos, in which no ectopic PGCs were found. In addition, these cells did not stain positively for the germ cell markers MVH and Stage-Specific Embryonic Antigen-1 (SSEA-1), suggesting that they are GFPpositive due to leaky expression of the transgene and are not germ cells. Although all $\mathrm{Bax}^{-/-}$embryos had extragonadal PGCs, the numbers of these were highly variable, suggesting variable penetrance of the phenotype. A possible reason for this variability was the mixed genetic background of the mice used. At E14.5, the average number of extragonadal abdominal PGCs was 2500 (data not shown), with many of these in groups or clumps. No significant differences in extragonadal germ cell numbers were observed between female and male embryos.

\section{The extragonadal germ cell population is a mixed one, with some retaining properties of migratory germ cells, and some partially differentiating}

The above data suggest that extragonadal germ cells can turn on markers normally turned on when they have reached the gonads. It was not clear to what degree extragonadal PGCs differentiate along the gonocyte lineage, and whether they all do so. We therefore stained sections for markers of migrating germ cells (SSEA-1), and markers of gonocytes (MVH, Scp3). We also assessed the degree to which they could give rise to EG cell colonies, and whether or not they remained motile.

Immunostaining was performed on embryo sections at stages based on important events during gonadal germ cell development: E10.5 - PGCs are actively migrating, dividing, and erasing parental imprints; E12.5 - migration has ceased and PGCs coalesce with gonadal somatic cells; E14.5 and E17.5 - meiosis has begun (female) and mitosis has ceased (male). The following antigens were chosen for immunostaining: SSEA1 - a Lewis $x$ carbohydrate antigen that is highly expressed in PGCs during migration, and is downregulated in gonadal germ cells from E12.5 until E15.0, with no expression thereafter (Kudo et al., 2004); Oct4 - a POU family transcription factor that is involved in maintaining pluripotency, is essential for PGC survival (Kehler et al., 2004), and is inactivated in female germ cells as they enter meiosis (E13.5 - E15.5) and in male gonocytes late in gestation, though it is later reactivated in some spermatogonia (Kehler et al., 2004). For this, the Oct4 $\Delta$ PE-EGFP-transgene was used as a marker. Mouse Vasa Homolog (MVH) - a PGC-specific RNA helicase that is upregulated around $\mathrm{E} 11.5$, as PGCs arrive at the genital ridges, and remains on throughout embryogenesis and in spermatocytes postnatally (Fujiwara et al., 1994). Synaptonemal complex protein 3 (Scp3) - a chromatin cohesin that is activated in the leptotene phase of meiotic prophase I, and remains on through the diplotene phase, late in gestation (Di Carlo et al., 2000). For reference, genital ridges and gonads at each stage were first immunostained with these markers. As reported previously (Anderson et al., 2000, Fujiwara et al., 1994, Marani et al., 1986), migratory PGCs at E10.5 nearly all expressed Oct4 and
Fig. 1. Extragonadal germ cells persist in Bax null embryos and inactivate Oct4. (A,B) Green fluorescent protein (GFP) imaging of whole mount embryos after removal of the ventral body wall and non-retroperitoneal organs for visualization of the abdominal retroperitoneum (kidneys also removed in $A$ ). (A) Male and (B) female E17.5 Bax null embryos have extragonadal germ cells scattered along the dorsal body wall, often with large clumps along the dorsal aorta larrowheads in A). (C) Abdominal transverse section of an E17.5 Bax null embryo showing clumps of mouse vasa homolog (MVH)-immunostained (Red) germ cells near the lumen of the inferior vena cava (IVC). (D) Abdominal, transverse section of the midline dorsal body wall of a postnatal day 2 (P2) Bax null pup shows ectopic germ cells that express MVH despite perinatal downregulation of the Oct4DPE-EGFP transgene. Sagittal (E,F) and transverse $\mathbf{( G , H ) ~ s e c - ~}$ tions of E17.5 Bax null embryos; extragonadal PGCs were frequently observed (E) near the dorsal aorta and (F) other large vessels, and (G) in and around the adrenal glands. (H) GFP+ cells within the thymus did not have germ celllike morphology, nor did they express germ cell markers. The dotted lines in (G) depict the boundaries of the adrenal gland. Bars represent $50 \mu \mathrm{m}$. Abbreviations: Ad, adrenal gland; Ao, aorta; K, kidney; O, ovary; RA, renal artery; $T$, testis, Thy, thymus.
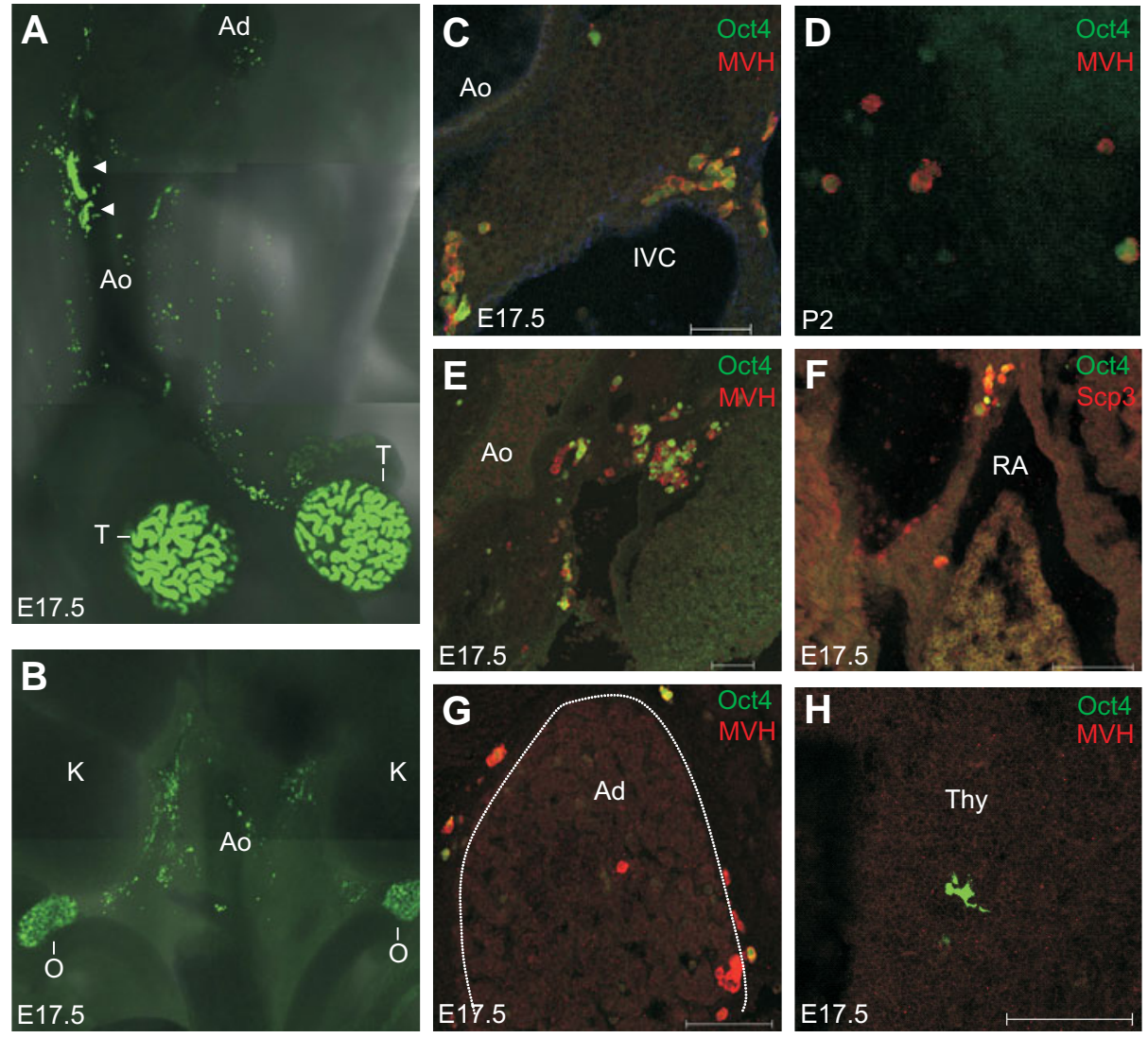

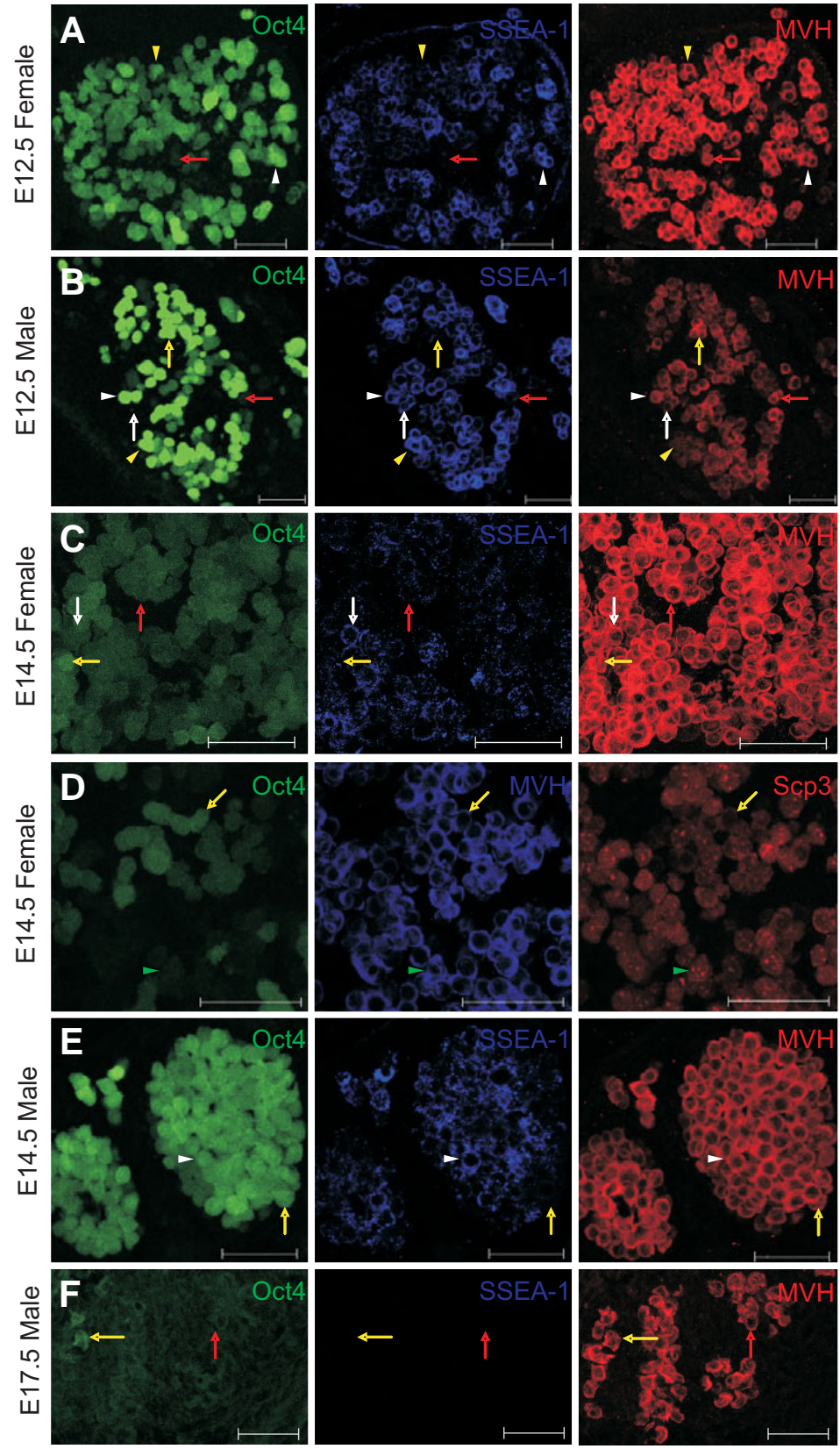

SSEA-1, but not MVH and Scp3 (not shown). By E12.5, MVH was activated in most PGCs in both female and male gonads (Figs. 2A,B). Some Oct4 and/or SSEA-1-negative (but MVH-positive) germ cells were identifiable at E12.5, particularly in the ovaries. In E14.5 ovaries, the staining intensity and numbers of Oct4 and SSEA-1-positive germ cells were greatly decreased (Fig. 2C), and Scp3 protein was highly expressed (Fig. 2D). Germ cells in the E14.5 testis similarly had fewer SSEA- $1^{+}$germ cells (Fig. 2E) but Scp3 was not expressed (not shown). By E17.5, SSEA-1 was absent and Oct4 was present in very few male and female gonocytes, but MVH was ubiquitously expressed (Fig. 2F). Scp3 was present in nearly all oocytes in some transverse sections of ovary, but in other sections was not detected at all (not shown), likely due to the rostral-caudal wave of Scp3 inactivation that occurs near this time period (Bullejos and Koopman, 2004).

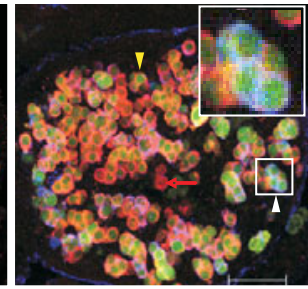

Fig. 2. Expression of Oct4, SSEA-1, MVH and Scp3 within gonadal germ cells at different stages. Triple fluorescent labeling of gonadal germ cells was performed on transverse, frozen sections for proteins in the upper-right corner of each panel. The fourth column is an overlay the 3 leftward images. Gonads from the following stages are shown: (A) E12.5 female, (B) E12.5 male, (C,D) E14.5 female, (E) E14.5 male, and (F) E17.5 male. Different germ cells stained positively for different combinations of markers: Oct4/ SSEA-1/MVH-triple positive - white arrowheads, SSEA-1/MVH-double positive - white arrows, Oct4/SSEA-1-double positive - yellow arrowheads, Oct4/MVH-double positive - yellow arrows, Oct4/MVH/Scp3-triple positive-red arrowheads, MVH/Scp3-double positive - green arrowheads, MVH only - red arrows. For $(A, B)$, inset boxes in the overlay column show magnifications of marked regions, to better demonstrate coimmunostaining. Bars represent $100 \mu \mathrm{m}$.

Extragonadal PGCs generally maintained expression of Oct4 and SSEA-1, and delayed activation of $\mathrm{MVH}$ and Scp3 compared to gonadal germ cells. However, there was considerable heterogeneity of expression among extragonadal PGCs within the same embryo. Fig. 3 shows that within clumps of extragonadal germ cells, there were individual cells that were positive and negative for each of these markers (Figs. 3A-C). The locations of the extragonadal germ cells also influenced marker expression. Within the adrenal glands, consistent with previous reports (Upadhyay and Zamboni, 1982, Zamboniand Upadhyay, 1983), germ cells in both genders activated Scp3 (Fig. 3D), which is an early indicator of meiotic entry (Di Carlo, 2000). In contrast, PGCs immediately outside of the adrenals, though often Scp3-positive, usually maintained Oct4 expression (Fig. 3E).

These data show that some extragonadal germ cells retain expression of markers found in migratory PGCs. To test whether extragonadal PGCs remain functionally immature, they were tested for their ability to form EG colonies in culture. When cultured on feeder layer cells in the presence of bFGF, Leukemia Inhibitory Factor (LIF), and Steel, PGCs form pluripotent ES-like colonies, called embryonic germ (EG) cells. This ability is progressively lost as PGCs colonize the genital ridges, until just after E12.5, when they can no longer be derived (Donovan, 1998). As positive and negative controls, respectively, migrating PGCs from E9.5, and gonadal PGCs from E14.5 WT embryos were used to determine their incidences of EG colony formation. EG colonies were defined as clumps containing at least 5 Oct $4 \Delta P E-E G F P+$ cells after eight days of culture. Fig. 4A shows that E9.5 PGCs formed EG colonies at a rate of 71.5 per 1000 cells plated, and 

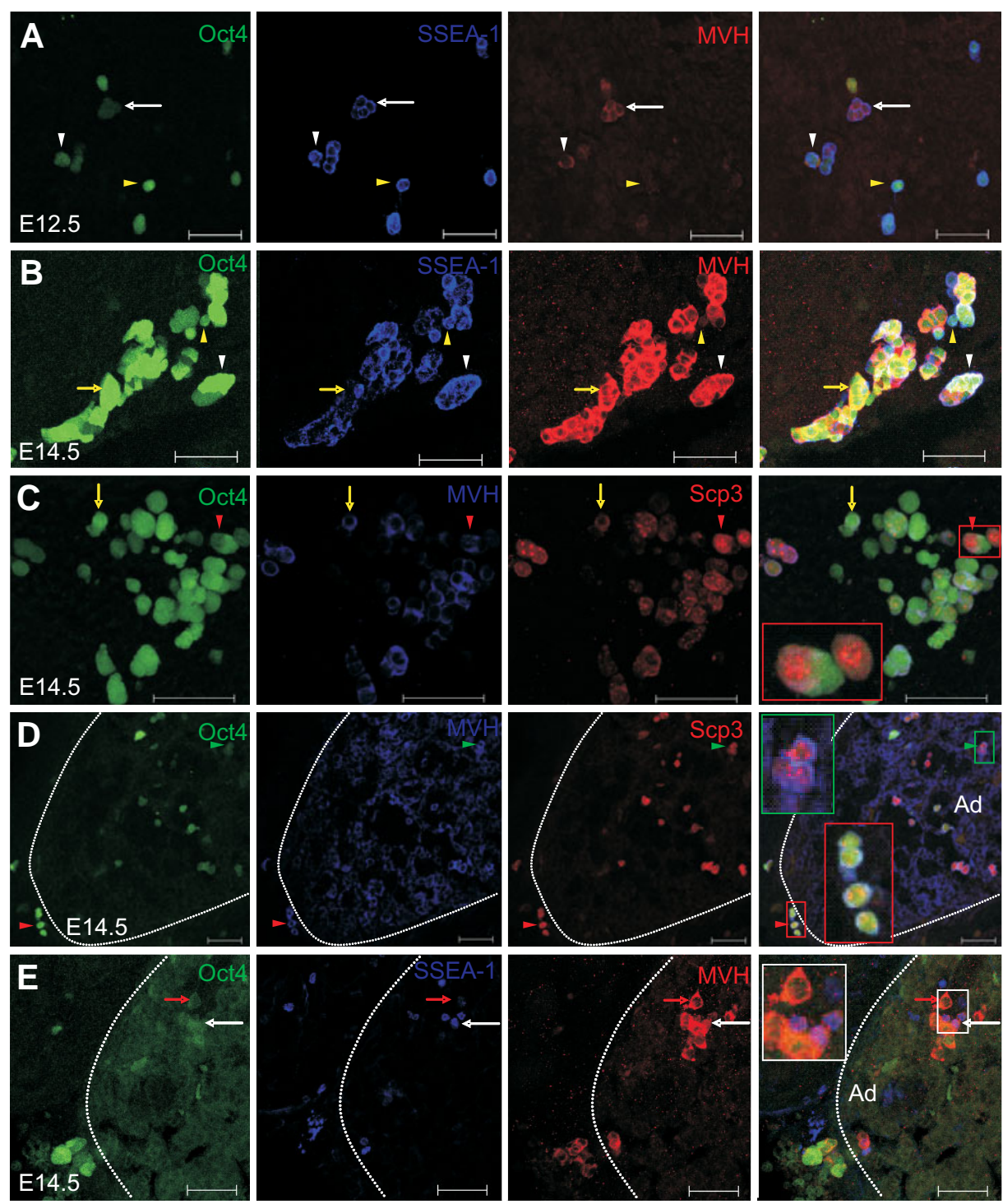

Fig. 3. Expression of Oct4, SSEA-1, MVH and Scp3 in extragonadal germ cells at different stages. Triple fluorescent imaging of extragonadal germ cells was performed on transverse, frozen sections for proteins in the upper-right corner of each panel. The fourth column is an overlay of the three leftward images. The following locations are shown: (A) the E12.5 abdominal midline, (B,C) the E14.5 abdominal midline, (D,E) the E14.5 adrenal gland, delineated from peri-adrenal germ cells by dotted line. Different germ cells stained positively for different combinations of markers: Oct4/ SSEA-1/MVH-triple positive - white arrowheads, SSEA-1/MVH-double positive - white arrows, Oct4/SSEA-1-double positive - yellow arrowheads, Oct4/MVH-double positive - yellow arrows, Oct4/MVH/Scp3-triple positive - red arrowheads, MVH/Scp3-double positive - green arrowheads, MVH only - red arrows. Inset boxes in the overlay column show magnifications of marked regions, to better demonstrate co-immunostaining. Abbreviations: Ad, adrenal gland. The dotted lines in $(D, E)$ depict the boundaries of the adrenal gland. Bars represent $50 \mu \mathrm{m}$.

these colonies contained only GFP+ cells (Fig. 4B). Germ cells from wildtype $\mathrm{E} 14.5$ gonads formed less than one colony per 1000 cells and most of these contained predominately GFP-negative cells (Fig. 4C). Gonads from E14.5 $\mathrm{Bax}^{-/-}$embryos had a significantly higher rate of $E G$ colony formation compared to WT gonads $(2.23 / 1000, p=0.002)$. Extragonadal PGCs formed $E G$ colonies at an even greater frequency $(8.14 / 1000, p=0.001$ compared to $\mathrm{Bax}^{-/}$gonads). EG colonies generated from E9.5 and extragonadal E14.5 PGCs were typically larger than those generated from
E14.5 gonads (compare Figs. 4D with $4 B, E)$. There were no differences in the rates of EG colony formation among gonads and midlines from either gender (not shown), thus each data point in Figure $4 \mathrm{~A}$ represents combined male and female samples. Although extragonadal PGCs could generate EG colonies, their efficiency was significantly lower than that of E9.5 PGCs $(p<0.001)$. This suggests that by not becoming incorporated into the gonads, some, but not all extragonadal PGCs retain a state of immaturity, sufficient for EG colony formation.

To assess whether extragonadal germ cells retain the ability to migrate, peri-aortic tissue explants from E13.5 and $16.5 \mathrm{Bax}^{-1}$

embryos were filmed using time-lapse microscopy. No germ cell migration was observed at either stage (not shown). Examination of E14.5 and E17.5 fixed sections for extragonadal germ cells in the abdomen furthermore showed that these PGCs did not extend migratory processes. Together, these data show that extragonadal germ cells within the abdomen are a heterogenous group. Many retain expression of early PGC markers, and some remain sufficiently undifferentiated to be able to generate EG colonies. However, most activate MVH and express scp3, an early marker of meiosis. By E13.5 none remain motile.

\section{Markers of migratory and gonadal germ cells reveal a novel population of extragonadal germ cells in the embry- onic tail}

Prior to E10 of mouse development, many cells within the tails of Oct $4 \Delta \mathrm{PE}$ EGFP mice are $\mathrm{GFP}^{+}$, presumably due to continued expression of Oct4 in the epiblast. Thereafter, GFP expression rapidly disappears. However, in Bax ${ }^{-/}$embryos a small number of $\mathrm{GFP}^{+}$cells remain. To test whether these cells were remnant epiblast cells, or PGCs, tail sections from E9.5 Bax 1- embryos were immunostained for SSEA1. Fig. $5 \mathrm{~A}$ shows a small subset of GFP. positive cells near the tip of the tail that exhibited cell processes and were also SSEA-1-positive, strongly suggesting that they were PGCs. Expression of SSEA-1 is not restricted to PGCs, and the presence of GFP-negative cells that expressed SSEA-1 in Fig. 5A likely represents a subset of epithelial cells (Fox et al., 1981). Examination of whole mount tails from E13.5 Bax ${ }^{-/}$embryos confirmed the presence of Oct $4 \Delta \mathrm{PE}$ $\mathrm{EGFP}^{+}$germ cells (Fig. 5B). In frozen sections of $\mathrm{Bax}^{-/}$sacral/tail regions, germ cells were identified in both epithelial and mesenchymal regions at all stages examined, but were absent from 


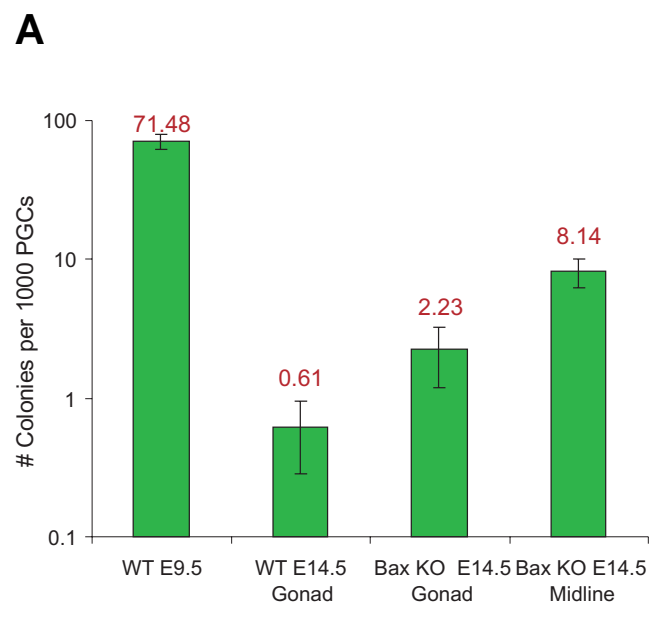

$\mathrm{Bax}^{+/-}$embryos. Sacral/tail PGCs were usually isolated or in small groups, and at E12.5 and E14.5, occasionally had filopodia suggestive of migration (Figs. 5C,D). Time lapse microscopy confirmed that, in contrast to periaortic germ cells, a small number of PGCs within the E13.5 tail were highly motile (not shown). These tail PGCs likely arise from germ cells that fail to become incorporated into the hindgut during gastrulation (Anderson et al., 2000). Another possibility is that they migrate from the hindgut into this ectopic site. To test this hypothesis, we made time-lapse movies of whole mount E9.0 Oct4 $\triangle$ PE-EGFP+ Bax mutant embryos to see whether germ cells within the hindgut could migrate
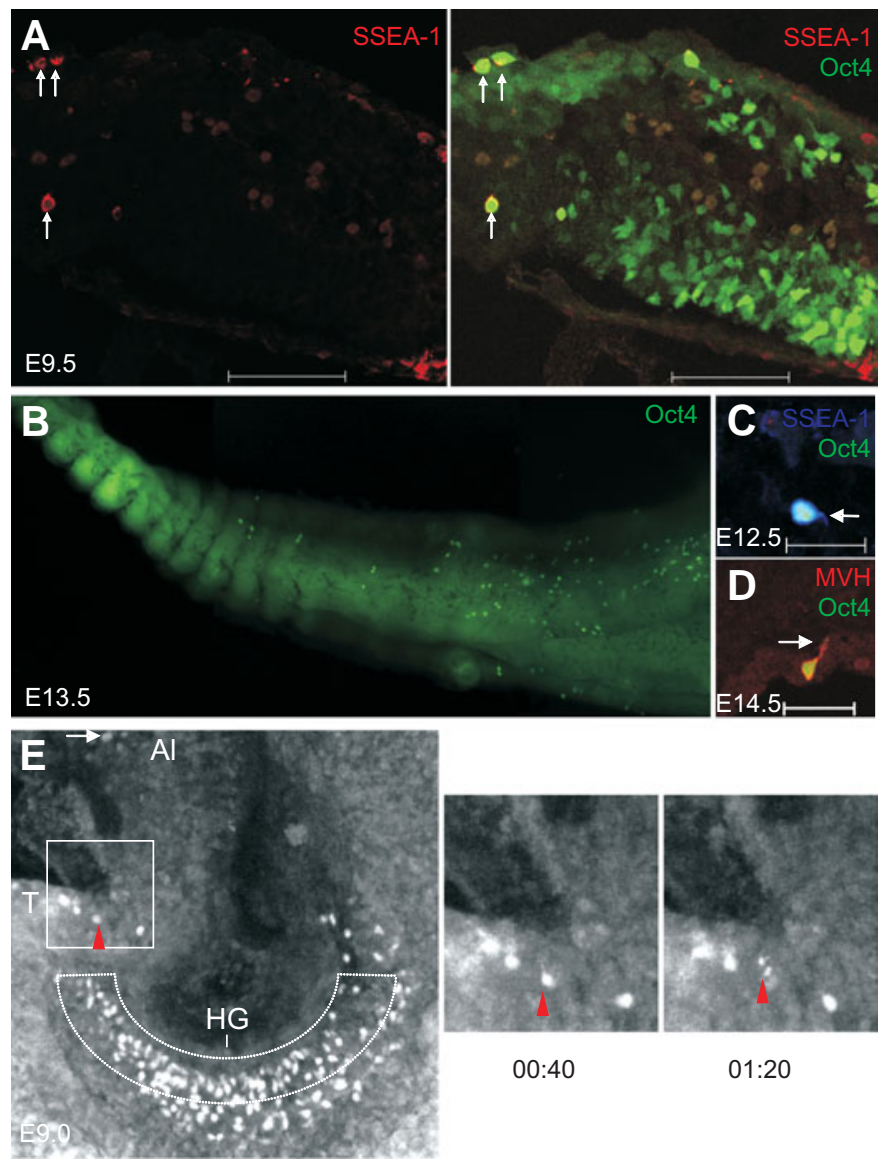
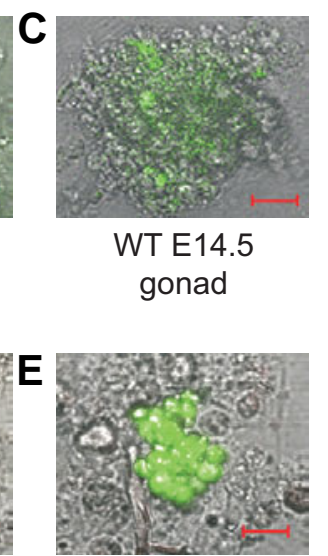

Bax KO

E14.5 midline
Fig. 4. Extragonadal germ cells can form embryonic germ (EG) colonies, but lose their ability to migrate. (A) The quantification of $E G$ colony-forming capacity per estimated number of plated cells is represented on a logarithmic scale. The average number of colonies generated per 1000 germ cells plated is shown in red over the corresponding bar. (B-E) Pictures of representative EG colonies from each group are shown. Bars represent $20 \mu \mathrm{m}$. Error bars are $95 \%$ confidence intervals.

into the tail and allantois. In $\mathrm{Bax}^{+/-}$and $\mathrm{Bax}^{+/+}$embryos, PGCs within the gut, allantois and tail were motile and appeared to undergo apoptosis, particularly in the latter structures (Fig. 5E). In $\mathrm{Bax}^{-/}$embryos, no PGC apoptosis was observed, nor was migration of germ cells from the hindgut to the tail (not shown). This suggests that, rather than migrating out of the caudal hindgut diverticulum, tail germ cells arise by late migration through the posterior primitive streak, as the node extends posteriorly during tail formation.

\section{The differential degrees of differentiation between genders and in different locations correlates with the different types of extragonadal GCTs}

Table 1 presented a summary of what is known about the type I and II GCTs. Given the diverse presentation of EGCTs in both genders, at different locations, and at different times of life, we sought to compare the differentiation of extragonadal germ cells in different locations and between males and females. To do so, germ cells in serial sections of E10.5-E17.5 whole embryos, both male and female, were systematically identified, placed into one of five groups based on location (see methods), and scored for expression of the early germ cell markers SSEA-1 and Oct4, and for markers of more differentiated gonocytes, MVH and Scp3.

Figure 6 shows that expression of early germ cell markers is prolonged in germ cells located extragonadally compared to those within the gonads and adrenal glands. For example, SSEA1 expression in E14.5 germ cells of the abdominal midline, sacral/

Fig. 5. Identification of extragonadal germ cells in the embryonic tail and sacral region. (A) Positive SSEA-1 immunostaining (Red, left panel) reveals a small subset of PGCs (arrows) among Oct4 $\triangle P E-E G F P^{+}$cells (Green, right panel) of the embryonic tail at E9.5. The caudal tip of the tail is to the right. (B) A whole mount tail at E13.5 shows numerous GFP+ germ cells, particularly near its base. (C,D) Continued expression of early germ cell markers and filopodia (white arrows) suggest a delay in differentiation of sacral/tail PGCS: (C) a SSEA-1/Oct4-double positive E12.5 sacral PGC and (D) a MVH/Oct4-double positive E14.5 tail PGC. (E) E9.0 embryos have PGCs in the hindgut (HG, marked by the dotted line), the tail (T) and the allantois (Al, see arrow). The inset marks a group of tail PGCs in a Baxt- embryo, one of which undergoes apoptosis (red arrowhead) as identified by time-lapse microscopy (elapsed time shown in hours:minutes). Scale bars represent $50 \mu \mathrm{m}$. 
tail and peri-adrenal regions was maintained despite downregulation in the gonads (Fig. 6A). However, by E17.5, few extragonadal PGCs expressed SSEA-1. Oct4 was similarly maintained in abdominal midline, sacral/tail and peri-adrenal germ cells compared to gonadal and adrenal germ cells at E14.5 and E17.5 (Fig. $6 \mathrm{~B})$. Interestingly, in female embryos, but not males, a higher percentage of germ cells in the tail/sacral region expressed Oct4 than those in the abdominal midline, at both $\mathrm{E} 14.5(\mathrm{p}=0.018)$ and $E 17.5(p=0.003)$. Furthermore, a higher percentage of germ cells in the sacral/tail region of female embryos expressed Oct4 through $E 17.5$, than in the male $(p=0.035)$. These data show that two markers of early, undifferentiated germ cells are maintained in extragonadal germ cells when they are switched off in the gonad. Further, Oct4 expression was maintained at higher percentages in sacral/tail germ cells than those in any other location.

\section{A}
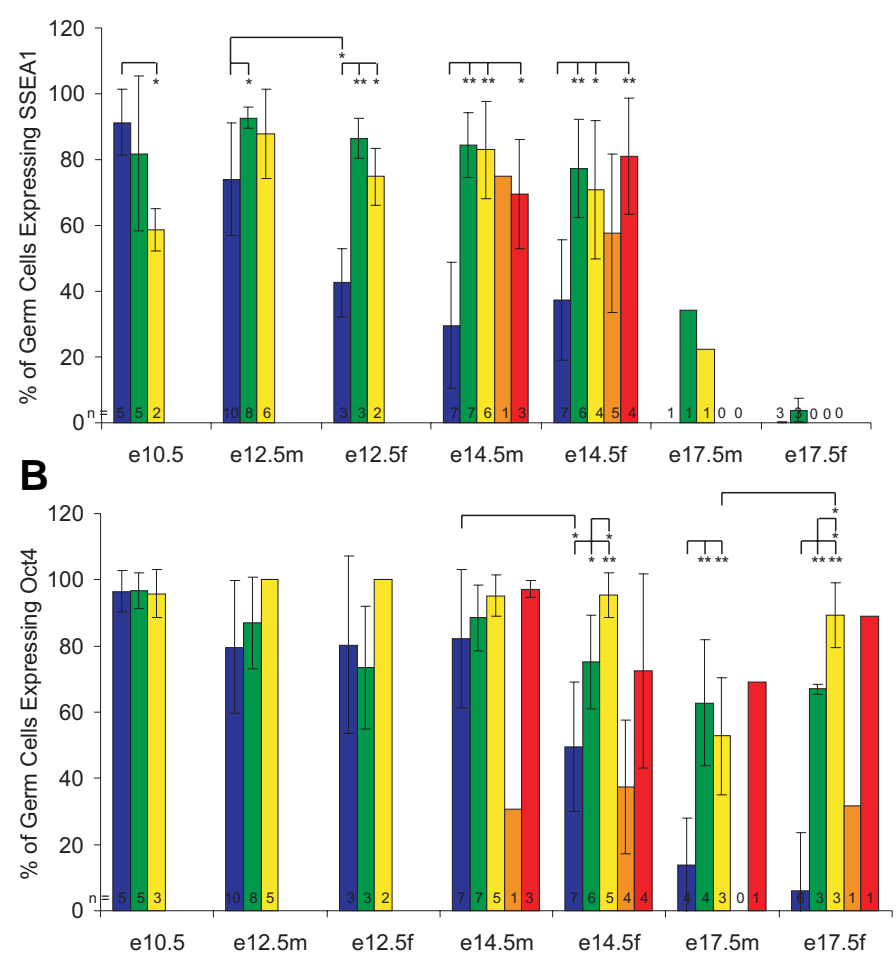

The percentage of germ cells expressing the gonocyte marker, $\mathrm{MVH}$, was lower in extragonadal germ cells of the abdominal midline and sacral/tail region in both genders compared to gonadal germ cells from E12.5 to E17.5 (Fig. 7A). As MVH expression approached $100 \%$ in gonadal germ cells, it also increased over time in extragonadal germ cells, though it did so earlier in germ cells within the abdominal midline compared to those in sacral/tail regions. For example, at E14.5, there was a significantly lower percentage of $\mathrm{MVH}^{+}$germ cells in the sacral/tail region compared to the abdominal midline for both males $(p=$ $0.047)$ and females $(p=0.004)$. By $E 17.5$, no difference was observed for the percentage of MVH germ cells within male sacral/tail regions and testis. However, a lower percentage of germ cells in female sacral/tail regions expressed $\mathrm{MVH}$ at E17.5 compared to germ cells in the ovary $(p=0.003)$ and in male sacral/

\section{A}
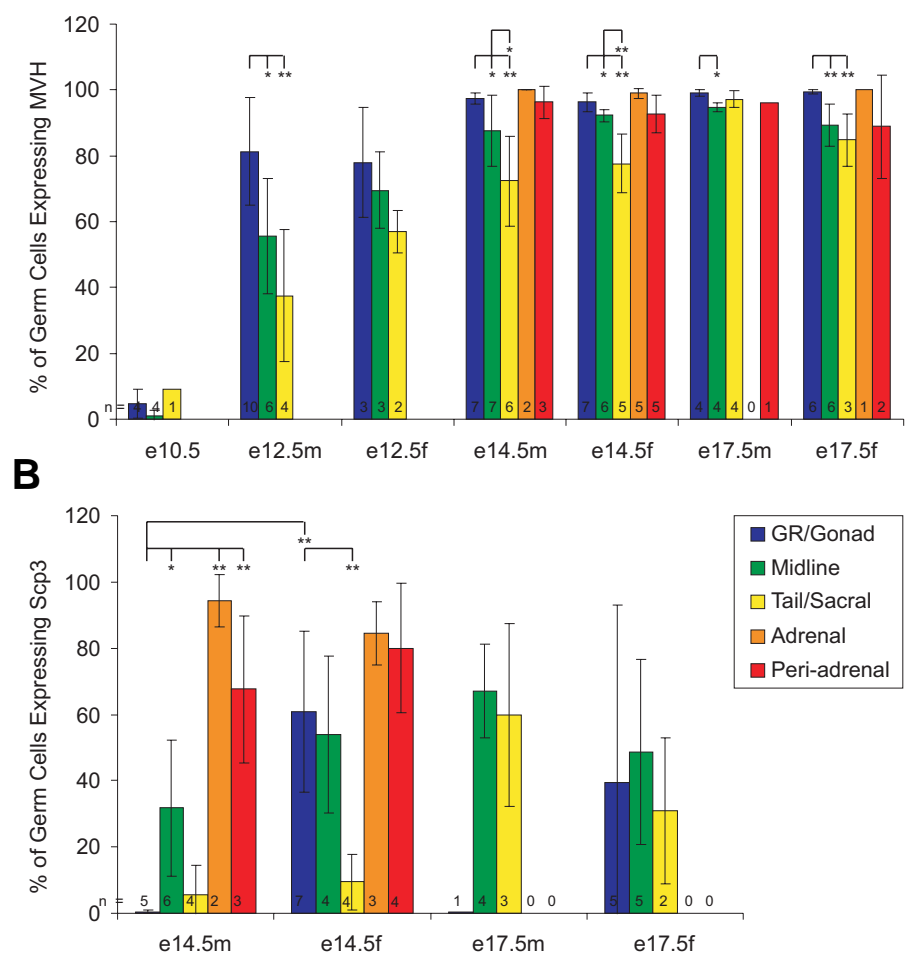

Fig. 6 (Left). Germ cell expression of SSEA-1 and Oct4 at different stages of development. These graphs show the percentages of germ cells that express (A) SSEA-1 or (B) Oct4DPE-EGFP at different stages within the gonads and 4 different extragonadal locations: the adrenal glands, periadrenal tissues, the abdominal midline, and the sacral/tail region. To collect the data, whole Oct4APE-EGFP+ Bax-null embryos from 4 different stages (E10.5, E12.5, E14.5 and E17.5) were serially sectioned and immunostained for SSEA-1 and MVH. Cells were identified as germ cells as follows: for E10.5 embryos, those expressing Oct4DPE-EGFP or SSEA1 with proper migratory PGC morphology (ie. cell processes), and for E12.5-E17.5 embryos, those expressing Oct4DPE-EGFP or MVH. Within each of the 5 locations, each individual germ cell was counted and scored for positive or negative expression of Oct4 (GFP), SSEA1 and MVH. Difference in gender was recorded for post-migratory stages (' $m$ ' - male, ' $f$ ' - female). The error bars represent standard deviations. Asterices represent the $p$ values generated from Student $T$ tests, ${ }^{*}, p<0.05$; ${ }^{*}, p<0.005$. The ' $n$ ' values near the $X$ axis show the numbers of embryos scored in a particular location/stage. See Materials and Methods for further detail.

Fig. 7 (Right). Germ cell expression of mouse vasa hom olog (MVH) and Scp3 at different stages of development. This graph shows the percentage of (A) Oct4DPE-EGFP+ germ cells that also expressed MVH in E10.5, E12.5, E14.5 and E17.5 embryos, or (B) Oct4 $1 P E-E G F P^{+}$and/or MVH ${ }^{+}$ germ cells that also expressed Scp3 in E14.5 and E17.5 embryos, in both genders (' $m$ ' - male, ' $f$ ' - female), in the 5 different general locations listed in the inset legend. To obtain the data, MVH/SSEA1- or MVH/Scp3-double-immunostaining was performed on Bax-null Oct4APE-EGFP+ frozen, serial sections from whole embryos and individual germ cells were counted and scored for positive or negative expression of each marker. The error bars represent standard deviations. Asterices represent the $p$ values generated from Student $T$ tests, ${ }^{*}, p<0.05$; ${ }^{* *}, p<0.005$. The ' $n$ ' values near the $X$ axis show the numbers of embryos scored in a particular location/stage. 


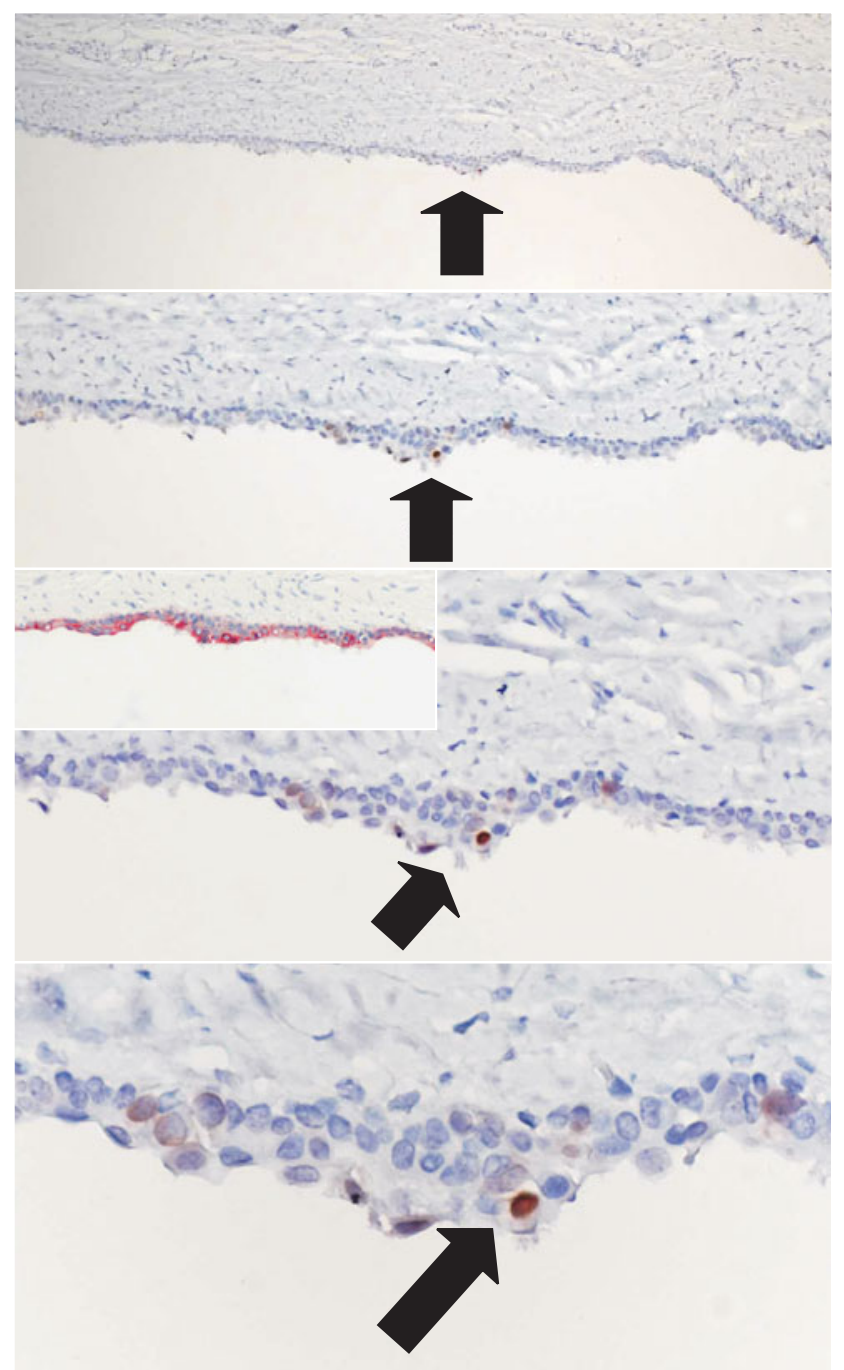

Fig. 8. OCT4-positive cells in a human sacral epithelial structure, near a sacrococcygeal teratoma. Immunohistochemical detection of OCT4 in paraffin embedded tissue from a nine day-old female with a sacrococcygeal teratoma. Multiple OCT4-positive cells (visualized in brown) are identified in an epithelial structure (positive for cytokeratin, visualized in red, insert). Four different magnifications are indicated (from top to bottom: 60x, 120x, 240x, 480x).

tail regions $(p=0.060)$. Scp3 expression was present in abdominal midline germ cells, and in those both in and around the adrenal glands at a percentage similar to that of ovarian germ cells at E14.5 (Fig. 7B). Unlike extragonadal germ cells in other locations, very few sacral/tail germ cells in both males and females expressed Scp3 at E14.5. By E17.5, however, percentages of Scp3+ sacral/tail germ cells had increased, particularly in the male $(60 \%)$ where it was nearly double that in the female $(31 \%, p=0.308)$. These data show that the activation of gonocyte markers is decreased in extragonadal germ cells, especially those in the sacral/tail regions. The data also suggest that germ cells that fail to reach the gonads do not follow a uniform sequence of differentiation steps. In different niches containing extragonadal PGCs, and even within clumps of PGCs within one niche, there were large variations in patterns of marker expression, and these patterns did not always mirror those seen in gonadal germ cells.
For example, in the ovaries and adrenal glands, germ cells that expressed Scp3 switched off Oct4 (in the ovary, 38\% and 1\% were $\mathrm{GFP}^{+}$at $\mathrm{E} 14.5$ and $\mathrm{E} 17.5$ respectively), but $\mathrm{Scp}^{+}$germ cells in the abdominal midline and sacral/tail regions maintained Oct4 expression (87\% and 65\% for tail germ cells at E14.5 and E17.5, respectively).

In summary, these data show that when unable to undergo apoptosis, extragonadal germ cells in the mouse naturally accumulate in many subdiaphragmatic midline locations, including the areas of Type I EGCT formation such as the sacrococcygeal region. Furthermore, they undergo a variable amount of activation of gonocyte differentiation, depending both on location and gender. The data suggest that within the adrenal glands, the timing of inactivation of early PGC markers, and activation of $\mathrm{MVH}$ and meiotic entry is similar to that of ovarian germ cells. They also suggest that the most caudally-localized extragonadal germ cells have the greatest delay of maturation, including delayed meiotic entry. This variability suggests they are probably responding to local signals that are different in different regions of the embryo.

\section{The identification of OCT3/4-positive cells in human sacro- coccygeal tissues}

A major argument against the theory that germ cells give rise to EGCTs, is that extragonadal germ cells have never been identified in human tissues outside of tumors. The finding that sacrococcygeal germ cells in $\mathrm{Bax}^{-/-}$embryos maintain expression of the early marker Oct4, suggested that Oct4 may be a useful marker for identification of extragonadal germ cells in humans. To test this, the resected sacrococcygeal tumors and adjacent nontumor-containing coccyges of 12 neonates and infants with a proven type I GCT were immunostained using an antibody specific for human OCT4 protein. No tumors contained OCT4 ${ }^{+}$cells. However positive cells were identified in an epithelial structure from one sample (9-day old female with teratoma, Fig. 8).

\section{Discussion}

A number of interesting points have emerged from the study of primordial germ cells in Bax ${ }^{-/}$embryos. First, and shown previously (Stallock et al., 2003), at E10.5 midline germ cells that are not eliminated by apoptosis do not continue their migration to the genital ridges, but remain in ectopic locations. During the period from E9.5, when germ cells do migrate from the midline towards the genital ridges, to E10.5, when they do not, the embryo grows almost two-fold in size. This supports a model in which chemoattractants such as SDF1 (Molyneaux et al., 2003) are short range signals, and embryo growth generates populations of germ cells along the migratory route, which are out of range of signals from the genital ridges, and are eliminated by withdrawal of survival factors.

Second, the loss of Bax is not sufficient on its own for the formation of EGCTs. In this study, we examined postnatal Bax ${ }^{-/}$ mice for the presence of these, but did not find any (data not shown). This suggests that an additional oncogenic event is required for germ cell tumor formation. Although defects in the apoptotic pathway may not be a primary cause of EGCTs, they may synergize with other causes, because a recent report shows a correlation between mutations in Bax, or low Bax protein expression, and the localization of pediatric GCTs in the sacro- 
coccygeal region (Addeo et al., 2007).

Third, and shown in this paper, is the fact that extragonadal germ cells that are not eliminated by apoptosis form a heterogeneous population of cells, depending on position in the embryo and gender. EGCTs are found in a large number of locations along the cranio-caudal axis, from the pineal gland to the coccyx. They are always in the midline. Time of incidence, and type of tumor, seem to correlate with position along the cranio-caudal axis, and gender. Sacrococcygeal tumors are more common in infancy, more common in females, and are always teratomas or yolk sac tumors (or a mixture of the two), and make up the majority of type IGCTs (Oosterhuis and Looijenga, 2005, Oosterhuis etal., 2007). They are thought to arise from early migratory germ cells that, based upon their widespread erasure of imprinting and sex chromosome studies, have not entered meiosis (Schneider et al., 2001, Wagner et al., 1997). In contrast, mediastinal tumors are more common in adolescence, more common in males, and are seminomas, or tumors derived from them including teratomas, and are grouped with type II GCTs (Oosterhuis and Looijenga, 2005). These tumors are thought to arise from germ cells of a slightly later stage and share cytogenetic malformations with post-pubertal gonadal GCTs (Schneider et al., 2002).

Since EGCTs are thought to arise from extragonadal PGCs, can our observations on the locations and behavior of extragonadal germ cells in the mouse explain these correlations? To a certain extent, they do. We found a previously undescribed population of extragonadal germ cells in the tail. These apparently do not enter the hindgut from the primitive streak (or migrate posteriorly from the gut into the tail mesentery). They retain more primitive features of the germ line, have a lower incidence of entry into meiosis, and retain more primitive germ cell features in the female than the male. Since the mouse tail corresponds to the coccyx in the human, these data suggest the hypothesis that germ cells in the sacral/tail region, which have not entered meiosis, might be the population of origin for type I sacrococcygeal tumors in human neonates. This idea is supported, but by no means proven, by the coccygeal sample from a single patient in which Oct4-positive cells were found in the epithelium adjacent to a tumor. It is possible that this cell was not a germ cell, since Oct4 would also be retained by primitive epiblast cells. It would be interesting to know if epiblast cells that are not germ cells can also colonize the tail. This could be tested using transgenic mice in which a reporter is expressed under the control of a promoter which drives expression in the epiblast, but not in germ cells. Further study with antibodies specific to human germ cells, and which distinguish them from primitive epiblast cells, would also be useful. Whichever is the case, it indicates that a larger study would be of interest, especially of younger time points, including embryonic tissues, in which tumors have not yet formed. In contrast, extragonadal PGCs in the abdominal region, though much more numerous than those in the tail, were found to differentiate at a much higher incidence which supports the finding that far fewer type I EGCTs occur in the abdominal retroperitoneum. Furthermore, the increased incidence of meiotic entry of more cranial germ cells provides an explanation for the rare cases of infantile mediastinal teratomas that show meiotic imprinting patterns (Schneider et al., 2001).

However, there are features of human EGCTs that are not explained by studying the extragonadal PGCs in the mouse. We did not find any extragonadal germ cells in the brain, nor in the thymus, the sites where these tumors can be found. There are a number of potential reasons. First, germ cells may simply not colonize these areas in the mouse. Ectopic germ cells left in the midline in $\mathrm{Bax}^{-/}$embryos did not migrate very far, and rapidly lost their motility. In the human embryo germ cells could migrate further, due to a longer gestation period. Alternatively, more distant migration and colonization could be due to additional mutations which enable them to enter and exit the vasculature, as in the chicken embryo. Second, germ cells that do migrate into anterior structures could be killed off by Bax-independent death pathways. Third, PGCs that enter those regions could be signaled to differentiate into cell types that lose the markers we used. Fourth, we cannot exclude the possibility that human EGCTs in those locations don't come from germ cells at all, but are derived from other stem cell populations. Further studies are required to distinguish these possibilities.

The delayed differentiation of PGCs in the sacral/tail region suggest the importance of this extragonadal niche in EGCT formation. Repression of the retinoic acid (RA) signaling pathway in this niche may be important for maintenance of PGCs in an immature state. When present, RA induces differentiation and Oct4 inactivation in GCT cell lines (Looijenga et al., 2003), and is the trigger for activation of meiosis in vivo (Bowles et al., 2006, Koubova etal., 2006). The prevailing model of meiosis regulation, which is supported by our findings, is that meiotic germ cell entry is inhibited in the testis by the presence of a cytochrome P450 enzyme, Cyp26b1 (Bowles et al., 2006, Koubova et al., 2006). During development, a rostral/caudal gradient of retinoic acid (RA) signaling is established, with RA levels absent at the tail due to degradation by a similar enzyme, Cyp26a1 (Molotkova et al., 2005). This gradient may explain the maintenance of Oct4 and repression of Scp3 activation observed in germ cells in the sacral/ tail region. Further study of this pathway in this region may provide a better understanding of the mechanisms of type I EGCT formation.

Lastly, we still do not know the final fates of extragonadal germ cells lacking Bax at postnatal stages. There are several possibilities. First, they may be eliminated by a Bax-independent mechanism. For example, the extrinsic pathway, activated by Fas, is generally Bax-independent, and is known to be activated postnatally in testicular germ cells, and may be downstream of Steel/kit signaling at that time (Sakata et al., 2003). Second, they may die by a non-apoptotic mechanism such as autophagy. Third, they may differentiate into Oct4 and $\mathrm{MVH}$-negative tissues. In nonseminomatous GCTs including teratomas, germ cells have variable or no expression of Oct4 or Vasa (Honecker et al., 2006, Zeeman et al., 2002). Lastly, they could differentiate into somatic lineages. This occurs in teratomas, and in Drosophila embryos, loss of expression of nanos causes germ cells to turn on somatic cell markers (Hayashi et al., 2004). This issue will only be resolved by germ cell specific lineage analysis of Bax ${ }^{-/}$germ cells. This experiment awaits the availability of a germ cell-specific mouse Cre line.

\section{Materials and Methods}

\section{Mouse breeding, embryo preparation and genotyping}

Bax $^{-/-}$(Knudson et al., 1995), Oct $4 \Delta$ PE-EGFP+ (Anderson etal., 2000) embryos and pups were obtained by interbreeding $\mathrm{GFP}^{+/+}$, $\mathrm{Bax}^{+/-}$males 
with $\mathrm{Bax}^{-/}$females on an outbred background (C3H $\times$WC/ReJ $\times$FVB). Embryonic day 0.5 (E0.5) was assumed to be noon of the morning a vaginal plug was observed. Genomic DNA was obtained from yolk sacs, hands or feet, and genotypes were determined by PCR. The primers used were:

Oct4 $\triangle$ PE-EGFP (Yeom et al., 1996)

F-5'GGAGAGGTGAAACCGTCCCTAGG-3',

R-5'-GCATCGCCCTCGCCCTCGC-3';

Bax (Deckwerth et al., 1996)

EX5-F-5'-GAGCTGATCAGAACCATCATG-3',

IN5-R-5'GTTGACCAGAGTGGCGTAGG-3',

NeoPGK-R-5'CCGCTTCCATTGCTCAGCGG-3'. All animals were treated according to protocols by the Institutional Animal Care and Use Committee at Cincinnati Children's Hospital.

\section{Time lapse microscopy}

Tail halves of E9.0 embryos, or explants from tail epithelial or periaortic tissues and whole testes from E13.5 and E16.5 Bax ${ }^{-1-}$ embryos were filmed using a Zeiss LSM 510 confocal microscope with a heated stage insert as previously described (Molyneaux et al., 2001). Pictures were taken at 7 or 8 minute intervals, for 100 frames. Images in multiple $Z$ levels were acquired to minimize the visible loss of cells due to migration within the $Z$ axis, and the resultant movies were projected into a single plane.

\section{Embryonic germ (EG) colony cell culture}

PGCs were cultured under ES-like culture conditions to generate EG colonies (De Miguel and Donovan, 2003, Durcova-Hills et al., 2001, Horii et al., 2003, Kerr et al., 2006). Stromal cells expressing constitutively membrane-bound Steel factor (m220 cells, a kind gift from Dr. David Williams, CCHMC) were used as feeders, and were plated near confluency in gelatin-pretreated 24-well plates, with knockout DMEM media (Gibco) containing the following: Knockout Serum Replacement (20\%, Gibco), 1\% Penicillin/Streptomycin (MP Biomedicals), 1\% nonessential amino acids (Gibco), $2 \mathrm{mM}$ L-Glutamine (Gibco), and $0.1 \mathrm{mM}$ $\beta$-mercaptoethanol (Fisher Scientific). Prior to plating of PGCs, feeder cells were treated with $10 \mu \mathrm{g} / \mathrm{ml}$ mitomycin $C$ for 2 hours at $37^{\circ} \mathrm{C}$, then thoroughly washed. Tissues containing Oct $4 \Delta P E-E G F P+P G C s$ were disaggregated using Trypsin/EDTA and manual trituration. E9.5 trunk regions (minus neural tubes), and $\mathrm{E} 14.5$ gonads were both plated at a $1: 1$ sample-to-well ratio. Explants from $\mathrm{Bax}^{-/-}$embryos were manually dissected from the periaortic midline in the abdomen, and plated at a $1: 1$ explant-to-well ratio. Bax ${ }^{-/}$embryos were selected by the absence of pigmented retinal epithelium (they are chinchilla as adults) and by the presence of high numbers of ectopic germ cells throughout the dorsal body wall. Bax wildtype embryos were obtained from separate crosses of FVB (Oct4 $\triangle$ PE-EGFP ${ }^{+}$) males with CD1 females. To media containing germ cells, the following were added: $1000 \mathrm{U} / \mathrm{ml} \mathrm{LIF}$ (Chemicon), $2 \mathrm{ng} / \mathrm{ml}$ bFGF (Invitrogen), $10 \mathrm{ng} / \mathrm{ml} \mathrm{SCF}$ (R\&D Systems), and $10 \mu \mathrm{M}$ Forskolin (Sigma). After 6-7 days, the cultures were passaged (split 1:3) to fresh feeder cells. After 9 days of culture, EG colonies were imaged using the Zeiss LSM 510 confocal microscope for GFP-expression. Colonies containing at least $5 \mathrm{GFP}^{+}$cells were scored as EG colonies. The percent of colonies formed were calculated based upon the numbers of germ cells in e9.5 embryos (320), e14.5 gonads $(12,000)$ and e14.5 dorsal body walls $(4,200)$. Two-tailed Student T-tests with equal variances were performed to determine statistical significance.

\section{Immunofluorescence analysis on whole-mount embryos or frozen sections}

Embryo preparation and immunostaining was performed as previously described (Runyan et al., 2006). Staining reagents were used at the following dilutions: SSEA-1 (Santa Cruz \#21702) - 1:200, MVH 1:200 (Abcam \#13840), Scp3 (Santa Cruz \#33195) - 1:200, Cy5 anti- mouse IgM (all secondary reagents from Jackson Immuno) - 1:200, Cy3 or Cy5 goat-anti-mouse - 1:200, Biotinylated goat-anti-rabbit $1: 200$, Cy3 or Cy 5 streptavidin $-1: 200$. For double staining with MVH and Scp3 (both rabbit polyclonal antibodies), the first antibody (MVH) was used at a 1:2000 dilution, followed by amplification using biotinylated secondary antibodies and streptavidin. Antibody complexes were then fixed for 10 minutes with $4 \%$ PFA, and washed thoroughly. Staining with the second primary antibody then proceeded normally. Imaging was performed on an Axiovert 100M microscope equipped with a Zeiss LSM 510 confocal scanhead. Microscope specifications for imaging of EGFP-positive samples utilized a $488 \mathrm{~nm}$ Argon Ion laser, a 488/543/ 633 dichroic mirror, and a $505-550 \mathrm{~nm}$ band pass filter. For imaging Cy5-positive samples, a $633 \mathrm{~nm}$ HeNe laser and $650 \mathrm{~nm}$ long pass filter were used. Embryos and adult tissues were sectioned serially (except E17.5 embryos), and 1 to 3 slides from each group were stained and imaged. Negative controls (secondary antibody only) were carried out for all antibody staining reactions, and were negative (data not shown). All extragonadal germ cells were counted and scored based upon location and combinations of positive immunofluorescent signals, using Zeiss LSM Imaging software. Percentages of SSEA-1-, Oct4-, $\mathrm{MVH}$ - or Scp3-positive germ cells were calculated for each location in each embryo, with a minimum of 10 cells required in a particular location for inclusion. Extragonadal germ cell locations were grouped as follows: Gonad, Adrenal, Peri-adrenal (within $\sim 100 \mu \mathrm{m}$ of the adrenal gland), Abdominal midline (umbilical, perigonadal, gut mesentery, perivascular and perivertebral cells within the abdominal area), and Sacral/Tail (bladder, and peri-vertebral/vascular, mesenchymal and epithelial parts of the embryo, caudal to the abdomen). Unpaired, two-tailed Student T-tests with equal variances were used to determine statistical significance between groups of germ cells in the different embryos.

\section{Immunohistochemistry \& evaluation of human tissues}

Four micron thick tissue sections were cut from resected coccygeal tissues from patients with a known sacrococcygeal GCT (either teratoma or teratoma and yolk sac tumor) and $\mathrm{H} \& \mathrm{E}$-stained, and parallel sections were stained using immunohistochemistry for OCT3/4, as described previously (de Jong et al., 2005). Endogenous peroxidase activity was inactivated by incubation in $3 \% \mathrm{H}_{2} \mathrm{O}_{2}$ for $5 \mathrm{~min}$. Antigen retrieval was carried out by heating sections in $0.01 \mathrm{M}$ sodium citrate ( $\mathrm{pH} 6.0$ or 9.0 if Bouin fixated) under high pressure up to 1.2 bar. Endogenous biotin was blocked using an avidin/biotin blocking kit (SP2001; Vector Laboratories, Burlingame, CA, USA). The sections were incubated for $2 \mathrm{~h}$ at room temperature with a 1:1000 dilution of a monoclonal OCT3/4 antibody (sc-5279; Santa Cruz Biotechnology) directed against the $\mathrm{NH}_{2}$ terminus of the protein. Subsequently, a 1:200-diluted biotinylated rabbit-anti-mouse secondary antibody (E0413; Dako, Glostrup, Denmark) was applied and bound antibody complex was visualized using the horseradish peroxidase (HRP) avidin-biotin complex method. Sections were counterstained with haematoxylin. Twelve samples were tested, of which 10 were from females (eight pure teratomas and two mixed teratoma yolk sac tumors) and two from males (teratomas). The ages at time of diagnosis were: 6, 6, 6, 9, 14 days, 1, 3, 6, 12, 12 months (female) and 3 and 12 months (male). All cases were diagnosed as type I EGCT of the sacrocyccegeal region by an experienced pathologist (Dr. J.W. Oosterhuis, Erasmus MC, Department of Pathology, Rotterdam, The Netherlands). For each sample, 1 - 10 slides were examined per case, which included sections containing the coccyx, both epithelial and mesenchymal structures. The tumor itself was also investigated when present in the slides, although the absence of OCT4 positive cells is reported in these tumors (de Jong et al., 2005, Looijenga et al., 2003).

\section{Acknowlegdements}

J. Stoop and R. van Gurp for selecting the sacral tumors and 
performing the immunohistochemical stainings, and J.W. Oosterhuis for interpretating the results. Financial support from the Cincinnati Children's Hospital Research Foundation is gratefully acknowledged.

\section{References}

ADDEO, R., CRISCI, S., D'ANGELO, V., VINCENZI, B., CASALE, F., PETTINATO, G., DONOFRIO, V., BOLDRINI, R., ALAGGIO, R., COLLINI, P. et al. (2007). Bax mutation and overexpression inversely correlate with immature phenotype and prognosis of childhood germ cell tumors. Oncol Rep 17: 1155-61.

ANDERSON, R., COPELAND, T.K., SCHOLER, H., HEASMAN, J. and WYLIE, C. (2000). The onset of germ cell migration in the mouse embryo. Mech Dev91:618.

BEARD, J. (1904). The Germ-Cells: Part I. J Anat Physio/38: 341-59.

BERNSTEIN L, S.M., LIU L, DEAPEN D, FRIEDMAN D. (1999). Chapter X: Germ Cell, Trophoblastic and Other Gonadal Neoplasms. In Cancer Incidence and Survival among Children and Adolescents: United States SEER Program 19751995, (ed. RIES LAG, S. M., GURNEY JG, LINET M, TAMRA T, YOUNG JL, BUNIN GR). NIH Pub.No.99-4649, Bethesda.

BOWLES, J., KNIGHT, D., SMITH, C., WILHELM, D., RICHMAN, J., MAMIYA, S., YASHIRO, K., CHAWENGSAKSOPHAK, K., WILSON, M.J., ROSSANT, J. et al. (2006). Retinoid signaling determines germ cell fate in mice. Science 312: 596-600.

BULLEJOS, M. and KOOPMAN, P. (2004). Germ cells enter meiosis in a rostrocaudal wave during development of the mouse ovary. Mol Reprod Dev68: 4228.

CHAGANTI, R.S., RODRIGUEZ, E. and MATHEW, S. (1994). Origin of adult male mediastinal germ-cell tumours. Lancet 343: 1130-2.

DE JONG, J., STOOP, H., DOHLE, G.R., BANGMA, C.H., KLIFFEN, M., VAN ESSER, J.W., VAN DEN BENT, M., KROS, J.M., OOSTERHUIS, J.W. and LOOIJENGA, L.H. (2005). Diagnostic value of OCT3/4 for pre-invasive and invasive testicular germ cell tumours. J Patho/206: 242-9.

DE MIGUEL, M.P. and DONOVAN, P.J. (2003). Isolation and culture of embryonic germ cells. Methods Enzymo/365: 353-63.

DECKWERTH, T.L., ELLIOTT, J.L., KNUDSON, C.M., JOHNSON, E.M., JR., SNIDER, W.D. and KORSMEYER, S.J. (1996). BAX is required for neuronal death after trophic factor deprivation and during development. Neuron 17: 40111.

DEHNER, L.P. (1990). Germ cell tumors of the mediastinum. Semin Diagn Pathol 7: 266-84.

DI CARLO, A.D., TRAVIA, G. and DE FELICI, M. (2000). The meiotic specific synaptonemal complex protein SCP3 is expressed by female and male primordial germ cells of the mouse embryo. Int J Dev Bio/44: 241-4.

DONOVAN, P.J. (1998). The germ cell-the mother of all stem cells. Int J Dev Biol 42: 1043-50.

DURCOVA-HILLS, G., AINSCOUGH, J. and MCLAREN, A. (2001). Pluripotential stem cells derived from migrating primordial germ cells. Differentiation 68: 2206.

FOX, N., DAMJANOV, I., MARTINEZ-HERNANDEZ, A., KNOWLES, B.B. and SOLTER, D. (1981). Immunohistochemical localization of the early embryonic antigen (SSEA-1) in postimplantation mouse embryos and fetal and adult tissues. Dev Bio/83: 391-8.

FRANCAVILLA, S. and ZAMBONI, L. (1985). Differentiation of mouse ectopic germinal cells in intra- and perigonadal locations. J Exp Zoo/233: 101-9.

FUJIWARA, Y., KOMIYA, T., KAWABATA, H., SATO, M., FUJIMOTO, H., FURUSAWA, M. and NOCE, T. (1994). Isolation of a DEAD-family protein gene that encodes a murine homolog of Drosophila vasa and its specific expression in germ cell lineage. Proc Natl Acad Sci USA 91: 12258-62.

GATCOMBE, H.G., ASSIKIS, V., KOOBY, D. and JOHNSTONE, P.A. (2004). Primary retroperitoneal teratomas: a review of the literature. J Surg Onco/86: 107-13.

GOBEL, U., SCHNEIDER, D.T., CALAMINUS, G., HAAS, R.J., SCHMIDT, P. and HARMS, D. (2000). Germ-cell tumors in childhood and adolescence. GPOH MAKEI and the MAHO study groups. Ann Onco/11: 263-71.
HAYASHI, Y., HAYASHI, M. and KOBAYASHI, S. (2004). Nanos suppresses somatic cell fate in Drosophila germ line. Proc Nat/ Acad Sci USA 101: 1033842.

HONECKER, F., STOOP, H., MAYER, F., BOKEMEYER, C., CASTRILLON, D.H., LAU, Y.F., LOOIJENGA, L.H. and OOSTERHUIS, J.W. (2006). Germ cell lineage differentiation in non-seminomatous germ cell tumours. $J$ Patho/208: 395-400.

HORII, T., NAGAO, Y., TOKUNAGA, T. and IMAI, H. (2003). Serum-free culture of murine primordial germ cells and embryonic germ cells. Theriogenology 59: 1257-64.

KEHLER, J., TOLKUNOVA, E., KOSCHORZ, B., PESCE, M., GENTILE, L., BOIANI, M., LOMELI, H., NAGY, A., MCLAUGHLIN, K.J., SCHOLER, H.R. et al. (2004). Oct4 is required for primordial germ cell survival. EMBO Rep5: 107883.

KERR, C.L., SHAMBLOTT, M.J. and GEARHART, J.D. (2006). Pluripotent stem cells from germ cells. Methods Enzymo/419: 400-26.

KNUDSON, C.M., TUNG, K.S., TOURTELLOTTE, W.G., BROWN, G.A. and KORSMEYER, S.J. (1995). Bax-deficient mice with lymphoid hyperplasia and male germ cell death. Science 270: 96-9.

KOUBOVA, J., MENKE, D.B., ZHOU, Q., CAPEL, B., GRISWOLD, M.D. and PAGE, D.C. (2006). Retinoic acid regulates sex-specific timing of meiotic initiation in mice. Proc Natl Acad Sci USA 103: 2474-9.

KUDO, T., KANEKO, M., IWASAKI, H., TOGAYACHI, A., NISHIHARA, S., ABE, K. and NARIMATSU, H. (2004). Normal embryonic and germ cell development in mice lacking alpha 1,3-fucosyltransferase IX (Fut9) which show disappearance of stage-specific embryonic antigen 1. Mol Cel/ Bio/24: 4221-8.

LOOIJENGA, L.H., STOOP, H., DE LEEUW, H.P., DE GOUVEIA BRAZAO, C.A., GILLIS, A.J., VAN ROOZENDAAL, K.E., VAN ZOELEN, E.J., WEBER, R.F., WOLFFENBUTTEL, K.P., VAN DEKKEN, H. et al. (2003). POU5F1 (OCT3/4) identifies cells with pluripotent potential in human germ cell tumors. Cancer Res 63: 2244-50.

MARANI, E., VAN OERS, J.W., TETTEROO, P.A., POELMANN, R.E., VAN DER VEEKEN, J. and DEENEN, M.G. (1986). Stage specific embryonic carbohydrate surface antigens of primordial germ cells in mouse embryos: FAL (S.S.E.A.1) and globoside (S.S.E.A.-3). Acta Morphol Neerl Scand 24: 103-10.

MOLOTKOVA, N., MOLOTKOV, A., SIRBU, I.O. and DUESTER, G. (2005). Requirement of mesodermal retinoic acid generated by Raldh2 for posterior neural transformation. Mech Dev 122: 145-55.

MOLYNEAUX, K.A., STALLOCK, J., SCHAIBLE, K. and WYLIE, C. (2001). Timelapse analysis of living mouse germ cell migration. Dev Bio/240: 488-98.

MOLYNEAUX, K.A., ZINSZNER, H., KUNWAR, P.S., SCHAIBLE, K., STEBLER, J., SUNSHINE, M.J., O'BRIEN, W., RAZ, E., LITTMAN, D., WYLIE, C. et al. (2003). The chemokine SDF1/CXCL12 and its receptor CXCR4 regulate mouse germ cell migration and survival. Development 130: 4279-86.

OOSTERHUIS, J.W. and LOOIJENGA, L.H. (2005). Testicular germ-cell tumours in a broader perspective. Nat Rev Cancer 5: 210-22.

OOSTERHUIS, J.W., STOOP, H., HONECKER, F. and LOOIJENGA, L.H. (2007). Why human extragonadal germ cell tumours occur in the midline of the body: old concepts, new perspectives. Int J Andro/30: 256-63; discussion 263-4.

RUNYAN, C., SCHAIBLE, K., MOLYNEAUX, K., WANG, Z., LEVIN, L. and WYLIE, C. (2006). Steel factor controls midline cell death of primordial germ cells and is essential for their normal proliferation and migration. Development 133: 48619.

SAKATA, S., SAKAMAKI, K., WATANABE, K., NAKAMURA, N., TOYOKUNI, S., NISHIMUNE, Y., MORI, C. and YONEHARA, S. (2003). Involvement of death receptor Fas in germ cell degeneration in gonads of Kit-deficient $W(v) / W(v)$ mutant mice. Cell Death Differ 10: 676-86.

SCHMOLL, H.J. (2002). Extragonadal germ cell tumors. Ann Onco/13 Suppl 4:26572.

SCHNEIDER, D.T., SCHUSTER, A.E., FRITSCH, M.K., CALAMINUS, G., GOBEL, U., HARMS, D., LAUER, S., OLSON, T. and PERLMAN, E.J. (2002). Genetic analysis of mediastinal nonseminomatous germ cell tumors in children and adolescents. Genes Chromosomes Cancer 34: 115-25.

SCHNEIDER, D.T., SCHUSTER, A.E., FRITSCH, M.K., HU, J., OLSON, T., LAUER, S., GOBEL, U. and PERLMAN, E.J. (2001). Multipoint imprinting analysis indicates a common precursor cell for gonadal and nongonadal 
pediatric germ cell tumors. Cancer Res 61: 7268-76.

STALLOCK, J., MOLYNEAUX, K., SCHAIBLE, K., KNUDSON, C.M. and WYLIE, C. (2003). The pro-apoptotic gene Bax is required for the death of ectopic primordial germ cells during their migration in the mouse embryo. Development 130: 6589-97.

TANAKA, S.S., TOYOOKA, Y., AKASU, R., KATOH-FUKUI, Y., NAKAHARA, Y., SUZUKI, R., YOKOYAMA, M. and NOCE, T. (2000). The mouse homolog of Drosophila Vasa is required for the development of male germ cells. Genes Dev 14: 841-53.

TOYOOKA, Y., TSUNEKAWA, N., TAKAHASHI, Y., MATSUI, Y., SATOH, M. and NOCE, T. (2000). Expression and intracellular localization of mouse Vasahomologue protein during germ cell development. Mech Dev 93: 139-49.

UPADHYAY, S. and ZAMBONI, L. (1982). Ectopic germ cells: natural model for the study of germ cell sexual differentiation. Proc Nat/ Acad Sci USA 79: 6584-8. WAGNER, H., BARETTON, G.B., SCHNEIDERBANGER, K., NERLICH, A., BISE, K. and LOHRS, U. (1997). Sex chromosome determination in extragonadal teratomas by interphase cytogenetics: clues to histogenesis. Pediatr Pathol Lab Med 17: 401-12.

YEOM, Y.I., FUHRMANN, G., OVITT, C.E., BREHM, A., OHBO, K., GROSS, M., HUBNER, K. and SCHOLER, H.R. (1996). Germline regulatory element of Oct4 specific for the totipotent cycle of embryonal cells. Development 122: 881-94.

ZAMBONI, L. and UPADHYAY, S. (1983). Germ cell differentiation in mouse adrenal glands. J Exp Zoo/228: 173-93.

ZEEMAN, A.M., STOOP, H., BOTER, M., GILLIS, A.J., CASTRILLON, D.H., OOSTERHUIS, J.W. and LOOIJENGA, L.H. (2002). VASA is a specific marker for both normal and malignant human germ cells. Lab Invest 82: 159-66.

\section{Related, previously published Int. J. Dev. Biol. articles}

See our Special Issue Invasion in Cancer \& Embryonic Development edited by Marc Mareel and Juan Aréchaga at: http://www.ijdb.ehu.es/web/contents.php?vol=48\&issue=5-6

See our Special Issue Developmental Aspects of Neoplasia, edited by Ivan Damjanov and Antonio Martinez-Hernandez http://www.ijdb.ehu.es/web/contents.php?vol=37\&issue =1

See our recent Special Issue Ear Development edited by Fernando Giraldez and Bernd Fritzsch at: http://www.ijdb.ehu.es/web/contents.php?vol=51\&issue=6-7

Primordial germ cell migration

Kathleen Molyneaux and Christopher Wylie

Int. J. Dev. Biol. (2004) 48: 537-543

The meiotic specific synaptonemal complex protein SCP3 is expressed by female and male primordial germ cells of the mouse embryo.

A D Di Carlo, G Travia and M De Felici

Int. J. Dev. Biol. (2000) 44: 241-244
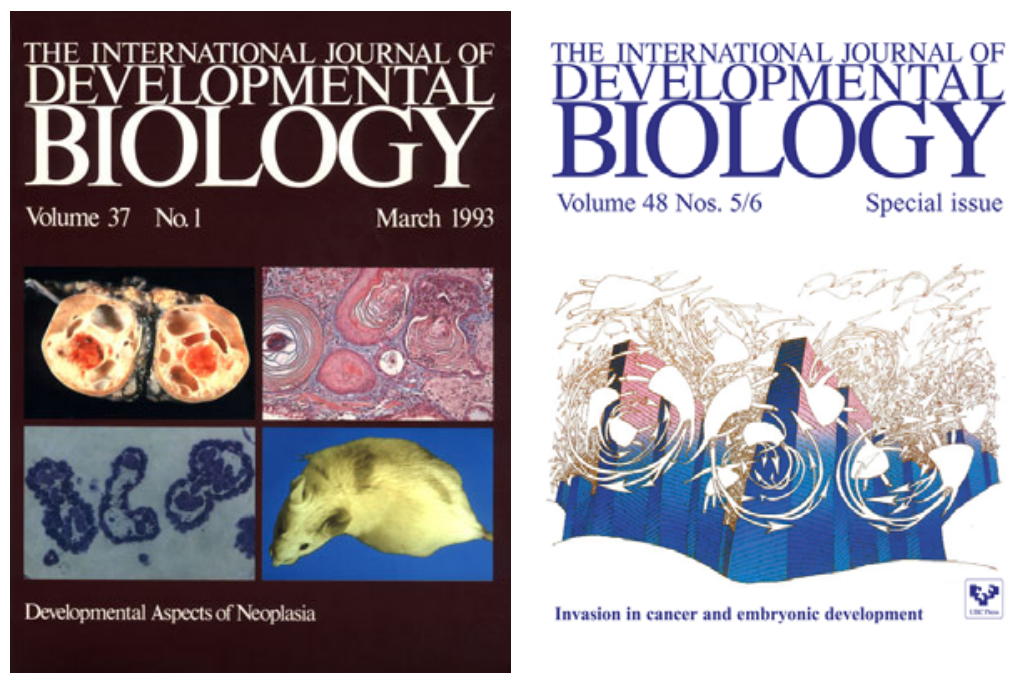

Volume 48 Nos. $5 / 6$

Special issue

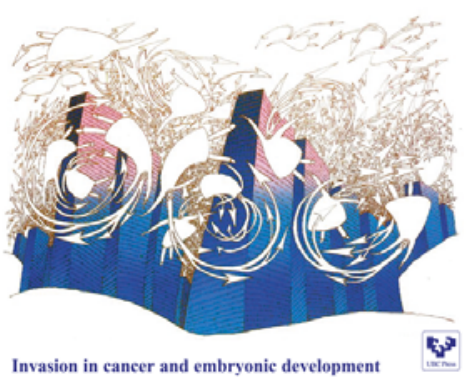

